\title{
Sevoflurane or desflurane: Which one is more expensive?
}

\author{
Robrecht De Medts, MD · Jan F. A. Hendrickx, MD, PhD • \\ André M. De Wolf, MD • Rik Carette, MD
}

Received: 24 September 2015 / Accepted: 3 November 2015/Published online: 16 December 2015

(C) Canadian Anesthesiologists' Society 2015

\section{To the Editor,}

The report by Tabing et al. ${ }^{1}$ describes how limiting the accessibility of cost-prohibitive drugs reduces overall anesthetic drug costs. Their article is timely given the decreasing availability of healthcare dollars (and euros!). Before referring to desflurane as a costly agent, however, we have to ensure that all aspects of drug delivery have been taken into account. While desflurane may be the more expensive inhaled agent, cost differences do depend on the manner in which the drug is delivered and titrated to effect.

First, there is no detailed information in the report on the actual fresh gas flows used. Second, was the synergy between opioids and potent inhaled anesthetics to provide unconsciousness, akinesia, and autonomic reflex control maximally exploited? Properly titrated opioids reduce the concentrations of the inhaled agents to achieve these clinical end goals by 15,50 , and $70 \%$, respectively. ${ }^{2,3}$ Third, what anesthesia machine technology was used during the study? Automated low-flow anesthesia machines can drastically reduce desflurane usage. In target-controlled low-flow mode, the Aisys ${ }^{\circledR}$ (GE, Madison, WI, USA), the FLOW-i ${ }^{\circledR}$ (Maquet, Solna, Sweden), and the Zeus ${ }^{\circledR}$ (Dräger, Lubeck, Germany) use maintenance fresh gas flows of 500, 300, and 180

This letter is accompanied by a reply. Please see Can J Anesth 2016; 63: this issue.

R. De Medts, MD ( $\varangle)$ · J. F. A. Hendrickx, MD, PhD .

R. Carette, MD

Departments of Anesthesiology, OLV Hospital, Aalst, Belgium e-mail: robrechtdemedts@hotmail.com

A. M. De Wolf, MD

Northwestern University Feinberg School of Medicine, Chicago, IL, USA
$\mathrm{mL} \cdot \mathrm{min}^{-1} \quad$ (closed-circuit anesthesia with $\mathrm{O}_{2} /$ air), respectively. After one hour, the mean (SD) usage of desflurane with a target concentration of $6 \%$ is 21.6 (1.9) $\mathrm{mL}$ and 14.2 (2.2) $\mathrm{mL}$ with the Aisys and Zeus, respectively. ${ }^{4}$ Fourth, the report does not mention whether $\mathrm{N}_{2} \mathrm{O}$ was used. While the effect of $\mathrm{N}_{2} \mathrm{O}$ on desflurane usage is complex and can be time dependent, ${ }^{5}$ $\mathrm{N}_{2} \mathrm{O}$ does reduce desflurane usage because the MAC of $\mathrm{N}_{2} \mathrm{O}$ and desflurane are additive. ${ }^{6}$ When desflurane is used with $\mathrm{O}_{2} / \mathrm{N}_{2} \mathrm{O}$ instead of $\mathrm{O}_{2} /$ air to maintain $1.3 \mathrm{MAC}$, target-controlled low-flow delivery with the FLOW-i reduces desflurane usage after one hour from an average of 26.6 to $7.4 \mathrm{~mL}$, a $72 \%$ reduction (unpublished observations, study in progress).

For desflurane to be less expensive than sevoflurane at equivalent MAC values, the cost of $1 \mathrm{~mL}$ of desflurane has to be approximately one-third or less of the cost of sevoflurane. How Tabing et al. ${ }^{1}$ calculated the cost of desflurane and sevoflurane to be $\$ 13.20$ and $\$ 0.63$ per case, respectively, a more than $2,000 \%$ difference, is enigmatic. When the absolute amounts of agent mentioned above are considered, it can be appreciated that the difference in cost between both drugs is close to being trivial if they are used at the lower end of the fresh gas flow spectrum, considering the entire cost of a surgical procedure.

It is rather a monolithic approach to limit the accessibility to desflurane by denoting it as a "costprohibitive drug" without having taken into account all the modalities of drug delivery. It is not the drug itself, but it is the delivery (i.e., the manner in which the agent is being used) that makes all the difference. As a profession, we have to be able to provide a more sophisticated approach to complex pharmacoeconomical questions lest we unnecessarily discard drugs whose properties may benefit our patients or a subset of patients. 
Acknowledgments Dr. Hendrickx has received lecture support, travel reimbursements, equipment loans, consulting fees and/or meeting organizational support of AbbVie, Acertys, Air Liquide, Allied healthcare, Armstrong Medical, Baxter, Draeger, GE, Hospithera, Heinen und Löwenstein, Intersurgical, Maquet, MDMS, MEDEC, Micropore, Molecular, NWS, Philips, Quantum Medical.

Conflicts of interest None declared.

\section{References}

1. Tabing AK, Ehrenfeld JM, Wanderer JP. Limiting the accessibility of cost-prohibitive drugs reduces overall anesthetic drug costs: a retrospective before and after analysis. Can J Anesth 2015; 62: 1045-54.
2. Katoh T, Ikeda K. The effects of fentanyl on sevoflurane requirements for loss of consciousness and skin incision. Anesthesiology 1998; 88: 18-24.

3. Katoh T, Kobayashi S, Suzuki A, Iwamoto T, Bito H, Ikeda K. The effect of fentanyl on sevoflurane requirements for somatic and sympathetic responses to surgical incision. Anesthesiology 1999; 90: 398-405

4. De Medts R, De Baerdemaeker A, Carette R, et al. Desflurane usage with two different automated target controlled low flow anesthesia machines. Anesthesiology 2013: A1060 (abstract).

5. De Cooman S, Lecain A, Sosnowski M, De Wolf AM, Hendrickx $J F$. Desflurane consumption with the Zeus during automated closed circuit versus low flow anesthesia. Acta Anaesthesiol Belg 2009; 60: 35-7.

6. Rampil IJ, Lockhart SH, Zwass MS, et al. Clinical characteristics of desflurane in surgical patients: minimum alveolar concentration. Anesthesiology 1991; 74: 429-33. 